\title{
SIN AND CRIME AS METAPHORS FOR THE REPRESENTATION OF EVIL IN YEATS'S THE COUNTESS CATHLEEN AND PURGATORY
}

\author{
Maria Rita Drumond Viana \\ Mestre em Literatura
}

\begin{abstract}
This article analyzes the representation of evil in two plays by $\mathrm{W}$. B. Yeats: The countess Cathleen (1892) and Purgatory (1939). Despite revealing different styles, the plays represent a concern with the nature of evil, salvation and damnation of the soul, and the individual's power against the forces of history.
\end{abstract}

\section{KEYWORDS}

W. B. Yeats (1865-1939), The countess Cathleen (1892), Purgatory (1939), Irish drama, evil

Despite the controversy over William Butler Yeats’s “religion” and the importance of mystic pursuit in the understanding of his œuvre, ${ }^{1}$ the poet and dramatist himself never had any doubts as to the centrality of a mystic vision in his life. In the first part of his Autobiographies: reveries over childhood and youth, originally published in 1914, Yeats ponders over his religiousness:

I am very religious, and deprived by Huxley and Tyndall, whom I detested, of the simple-minded religion of my childhood, I had made a new religion, almost an infallible Church of poetic tradition, of a fardel of stories, and of personages, and of emotions, inseparable from their first expression, passed on from generation to generation by poets and painters, with some help from philosophers and theologians. $^{2}$

From the start of his efforts as an artist, he had religion and art very closely linked, as were the figures of the priest and the poet - with a slightly greater praise for the latter's

\footnotetext{
${ }^{1}$ HOUGH. The mystery religion of W. B. Yeats, p. 5.

${ }^{2}$ YEATS. Autobiographies, p. 113.
} 
accomplishments. Grandson to a rector of Drumcliffe, where he would later find his final resting place “Under bare Ben Bulben’s head,” the "simple minded religion” of his childhood was Protestantism, under whose teachings he was raised, as befitted a member of the socalled Irish Protestant Ascendancy - even if his family was somewhat "fringe Ascendancy," and even "déclassé” ${ }^{3}$ as his father, John Butler Yeats, relinquished a career as a barrister in order to pursue an artistic life.

To his materialist father's discontentment, Yeats's idea of art necessarily included a religious basis. In a letter to the Fenian John O'Leary, Yeats defended himself against his father's charges of irrationalism:

Now as to Magic. It is surely absurd to hold me "weak" or otherwise because I chose to persist in a study which I decided deliberately four or five years ago to make, next to my poetry, the most important pursuit of my life. (...) If I had not made magic my constant study I could not have written a single word of my Blake book, nor would The Countess Kathleen ever come to exist. The mystical life is the centre of all that I do and all that I think and all that I write. ${ }^{4}$

What Yeats chooses to call Magic with a capital M was the practical side to his mystical pursuits into many religions and philosophies. Virginia Moore in her study of Yeats's religion proposes that his beliefs ranged from Paganism or Druidism to Hermeticism, with an intense Christian coloring not only in the Rosicrucian and Gnostic variations, but also with an understanding of Catholic and Protestant orthodoxy. Patrick J. Keane parallels her list and adds:

Yeats ranged speculatively through Platonism, Neoplatonism, and Christianity; Arabic and Indian philosophy; Buddhism and the spiritual implications of Japanese Noh drama; Irish mythology and folklore; Hermeticism, the Kabbala, Swedenborgian angelogy, Theosophy, psychical experiment, astrology, automatic writing, and the Lord knows what. ${ }^{5}$

To this list I would add that he was heavily influenced by mystics such as Boehme and by fellow poet and mystic William Blake, whose works he edited and annotated into the threevolume edition mentioned in the letter.

From this amalgam, Yeats derived many aspects of his own system of belief, which was later expounded in the two versions of $A$ vision $(1925 ; 1937)$ and related prose. In the essay "If I were four-and-twenty,” Yeats describes his life-long search for overreaching

\footnotetext{
${ }^{3}$ FOSTER. Yeats and Irish politics.

${ }^{4}$ YEATS. Autobiographies, p. 210-211.

${ }^{5}$ KEANE. Yeats's interactions with traditions, p. 110.
} 
explanations, for totalizing solutions, and for the need to unify his interests: "Hammer your thoughts into unity" was the sentence he tested all he did by. ${ }^{6}$ The same impulse propelled him in the writing of $A$ vision, described by Margaret Mills Harper as "part cosmology, part apocalypse, part psychoanalysis, part poetry, and part confusion”. 7 Of this volume, Yeats has commented:

I write [A vision] very much for the young men between twenty and thirty, as at that age, and younger, I wanted to feel that any poet I cared for Shelley let us say - saw more than he told of, had in some sense seen into the mystery. I read more into certain poems than they contained, to satisfy my interest. The young men I write for may not read my Vision - they may care too much for poetry - but they will be pleased that it exists. (...) I have constructed a myth, but then one can believe in a myth - one only assents to philosophy. ${ }^{8}$

Yeats draws here a traditional distinction between myth and philosophy, one that has great resonance in his work. In his study of Blake, he had come across the idea of the conflict between the individual and the universal, a conflict brought about from the breaking down of an original unity which included man and God. Even if the joining of the fragmented individual with the universal could only be possible with the restoration of the Golden Age, man still possessed an element of the universal that was "mood" or emotion. Thus, passions and emotions became holy, deriving from the universal. According to Leonard E. Nathan, in his reading of Blake Yeats found that "emotion, then, is associated with the good and the supernatural, while reason is associated with the evil and the natural”. ${ }^{9}$ In Yeats's own words:

The mischief began at the end of the seventeenth century when man became passive before mechanized nature. That lasted to our own day with the exception of a brief period between Smart's Song of David and the death of Byron, wherein imprisoned men beat upon the door. (...) Soul must become its own betrayer, its own deliverer, the mirror turn lamp. ${ }^{10}$

Reason was the realm of philosophy, whereas emotion was the realm of the mythical, of the religious, and of the arts.

The conflation of religion and art was even more patent in his drama than in his poetry or even in his more overtly mystical prose. The ritualistic aspect of drama was central to him,

\footnotetext{
${ }^{6}$ YEATS. Explorations, p. 163.

${ }^{7}$ HARPER. Yeats and the occult, p. 160.

${ }^{8}$ YEATS. Explorations, p. 781.

${ }^{9}$ NATHAN. The tragic drama of W. B. Yeats: figures in a dance, p. 3.

${ }^{10}$ YEATS. The collected works of W. B. Yeats: later essays, p. 194
} 
as he believed that the theater was "essentially defined by a ceremoniousness profoundly akin to religious ritual; the identification of theater with religious verse is one of those deeply held ideas that links Yeats's work from first to last”. ${ }^{11}$ Drama was for Yeats an extension of Magic, leading George Mills Harper and John S. Kelly to conclude that the founding of the Irish Literary Theatre "was, in part, an attempt to widen the scope of the Celtic Mysteries", ${ }^{12}$ Yeats's plan for a mystical society, an Irish-mythology based Order of the Golden Dawn.

In working on The countess Cathleen (1892), his first play performed by the Society and the first he included in his canon, and with Purgatory, a play included in his last, posthumously published, Last poems and two plays (1939), I intend to assess the development of his theory of evil in two main metaphors, as proposed by Julio Jeha: ${ }^{13} \sin$ and crime. Whereas in The countess Cathleen sin is seen mainly from a religious standpoint, the more encompassing portrayal of evil in its moral and social, as well as religious implications, in Purgatory reflects Yeats's development toward greater unity and is in accordance with this general trend in his work.

The two plays reveal radically different styles and are grounded on separate periods of Yeats's career. Nevertheless, a concern with the nature of evil, salvation and damnation of the soul, and the individual's power against the forces of history and fate create a thematic link between them that has not yet been explored.

By working with evil, I intend to evade the many divisions that Yeats scholars have traditionally employed in an attempt to deal with the multitude of identities he adopts throughout the long span of his artistic and public life. Richard Ellmann, in his very influential biography Yeats: the man and the masks, divides the figure of the poet into two opposing characters, who are taken from Yeats's prose and seen as his multiple alter egos: Owen Aherne, with whom Ellmann aligns his nationalist persona, and Michael Robartes, his mystical side. In the introduction to the first volume of the new biography, now seen as the standard work on Yeats, Roy Foster acknowledges some of the reasons that led to this division in different personalities:

Faced with the multifarious activities, the feints and turns, the wildly differing worlds which WBY [William Butler Yeats] embraced, Ellmann followed his subject's example in dealing with his life thematically: WBY's own Autobiographies dictate this arrangement for his life, and it is a

\footnotetext{
${ }^{11}$ NATHAN. The tragic drama of W. B. Yeats: figures in a dance, p. 12.

${ }^{12}$ HARPER; KELLY. Preliminary examination of the script of E[lizabeth] R[adcliffe], p. 131.

${ }^{13}$ JEHA. Monstros como metáforas do mal, p. 19.
} 
thematic one. (...) The natural reaction is (...) to deal with the periods of frantic and diverse involvements, as in the early 1900s, by separating out the strands of occultism, drama and love, and addressing them individually. ${ }^{14}$

This division is then understood in the context of the biography, the object of both Ellmann's and Foster's studies. Nevertheless, as the text points out, it was soon followed by several other studies. Although this division is justifiable by Yeats's own practices, I agree with Foster on the impossibility of separating these strands as they worked in shaping the composite identity of Yeats as an artist. Thus, even though my choice of methodology is in itself thematic, and therefore necessarily a selection, it does not seek to separate Yeats into two schizophrenic personalities.

Yeats is concerned with evil on many levels. In his system, evil is an important force of change, and knowledge of evil is necessary for the achievement of Unity of Being, the final state of ecstasy and of achievement. Helen Vendler explains the difference between two types, personified by Shelley and Dante: “According to the first edition of A Vision those idealists who hope for a 'final conquest' see only the Vision of Good; those who are content to struggle with no final conquest, who can truly love tragedy, have not only the Vision of Good but also that of Evil." 15 The idea of the eternal struggle is exemplified in the figure of the Irish mythological hero Cuchulain, who, in On Baile's strand (1904), finds tragic joy as he fights the invincible waves until he can do no more and falls, exhausted. Not having a Vision of Evil, for Yeats, makes a man unaware of an important part of his experience. In this sense, Yeats is close to Lucius Annaeus Seneca and other philosophers who contended a very similar point: "To be always happy and to pass life without a mental pang is to be ignorant of one half of nature.”16 Considering Yeats's emphasis on unity and on self-knowledge, knowing one half and not its contrary impeded the "beatific vision" of Phase 15, where Unity of Being is possible. Vendler thus defines this state:

The beatific vision of Phase 15 is, like its religious counterpart, at once simultaneous and whole: that is, in it all experience is integrated, everything finds its place. But it has one startling difference from the perfect joy of traditional ecstasy. It involves somehow a process of purgation, a time of pain, a passage through vision, where evil reveals itself in its final meaning. ${ }^{17}$

\footnotetext{
${ }^{14}$ FOSTER. W.B. Yeats: a life: the apprentice mage, p. xxvi-vii.

${ }^{15}$ VENDLER. Yeats's Vision and later plays, p. 264.

${ }^{16}$ LARRIMORE. The problem of evil: a reader, p. 20.

${ }^{17}$ VENDLER. Yeats's Vision and later plays, p. 25.
} 
In this phase, those who had not known evil come to see it, and those who had not known good experience it in a similar manner. As a self-declared disciple of Blake, Yeats agreed with the idea that "Without Contraries there is no progression", ${ }^{18}$ but not without qualification of the idea of progression; for him progress was a vulgar innovation of the Enlightenment. For the straight and forward-pointing line Yeats substituted the figure of the gyre and of the interconnecting cones. But for Yeats, only when the soul manages to regard both good and evil impassively can it ascend to a higher state. As long as it is bound to the distinction, it will be "caught in the treadmill of repetition". ${ }^{19}$ This repetition is enacted in Purgatory.

This idea of evil is closer to Blake's, and is in some ways an extension of the idea of the contraries:

It is hard to see how this odd type of evil [cruelty and ignorance] could be the conditions for the entrance of a species of Paradise: Yeats's metaphysics seems to have gone too far. But when we recall that for him, the cruelty of the beloved and the ignorance of the lover (themes which recur so often in the plays) were the two essential ingredients for a tenacious passion, the passage becomes less obscure. ${ }^{20}$

The evil here alluded is then seen as both the genesis of passion, an important characteristic of the hero, and as a source of adversities to be (at least in an attempt) overcome.

For Yeats, this is the other facet to evil. In $A$ vision, he states that "evil is that which opposes Unity of Being”. ${ }^{21}$ This depiction is closer to St. Augustine's, who defines evil as "merely the privation of good". ${ }^{22}$ It seems contradictory that evil is necessary for achieving Unity of Being while also impeding it. Nevertheless, Yeats's focus on struggle, on the process rather than on the result, dissolves this contradiction as it makes evil an obstacle to conquer. It is a doctrine of perfectibility: in The countess Cathleen, the evil that decimates the land leads the heroine to her final sacrifice, which in turn saves and immortalizes her.

The fighting of evil or even smaller adversities is, for Yeats, a heroic struggle, and thus leads to a greater good. In his essay "Monstros como metáforas do mal," Julio Jeha distinguishes several approaches to evil, one of which he ascribes to Leibniz, who argues that the existence of evil makes courage, compassion, and self-sacrifice possible. ${ }^{23}$ Jeha objects $^{2}$

\footnotetext{
${ }^{18}$ BLAKE.The marriage of heaven and hell, p. 3.

${ }^{19}$ VENDLER. Yeats's Vision and later plays, p. 80.

${ }^{20}$ VENDLER. Yeats's Vision and later plays, p. 90.

${ }^{21}$ YEATS. The collected works of W. B. Yeats: a Vision: the original 1925, p. 190.

${ }^{22}$ LARRIMORE. The problem of evil: a reader, p. 56.

${ }^{23}$ JEHA. Monstros como metáforas do mal, p. 17.
} 
that these virtues would not be necessary had evil been excluded from creation, but the pragmatist in Yeats would retort it simply has not. Keane explores this pragmatism: "There were few qualities Yeats admired more than 'unwilling belief,' that is, capacity to acknowledge the limitations of rationalistic optimism and to accept the tragic facts of 'evil' and suffering.”24 Evil is intrinsically part of his system.

Because Yeats's system is without God, the existence of evil is never a problem for him, it is merely a given. Yet, despite its undeniable existence, agency is never ascribed to anyone in particular. As Vendler notes, Yeats's definition of evil as conflict means that evil is understood in no ordinary sense: "Of human bonds to earth as well as to heavens Yeats was well aware, but the Infernos of both Dante and Blake formed no part of his cosmology." 25 His cosmology included purgatory and a promise of ascension to heaven or at least a higher state of existence, but hell only features in St. Patrick's imprecations against Oisin in "The Wanderings of Oisin.” Evil is again seen as something that holds the soul back.

Since there is no God, and no devil, in The countess Cathleen except in the allegorical form of the merchants, all agency is attributed to a disembodied history or even fate. Determinism and free will are crucial in Yeats's understanding of history, and the description of the historical cycles, past and future, occupies an extensive part of $A$ vision. Patrick J. Keane elaborates on how Yeats's cycles and their determinism depart from the "grey truth" Yeats rejected:

How does the self, having rejected one machine (the Newtonian clockwork universe of dead matter in motion), find freedom and even exultation in a universe roughly calculable by wheels and interlocking gyres? Yeats's paradoxical solution - defining freedom as the recognition of necessity, asserting that creative man is at one "predestinate and free" - goes beyond stoic and Spinozistic fatalism to the astringent tragic joy of Nietzsche's similar recognition, culminating in Amor Fati and the embrace, whether fierce or serene, of Eternal Recurrence. ${ }^{26}$

The idea of Eternal Recurrence in its yeatsian fashioning is of course paramount to the discussion of Purgatory, but it is also relevant for the analysis of Yeats's understanding of

\footnotetext{
${ }^{24}$ KEANE. Yeats's interactions with traditions, p. 96.

${ }^{25}$ VENDLER. Yeats's Vision and later plays, p. 41.

${ }^{26}$ KEANE. Yeats's interactions with traditions, p. 18-19.
} 
evil, and how it figures in a world marked by such recurrence. In these cycles, evil is a necessity, even in its more metaphysical side:

The original Deluge, we recall, did not drown "the ceremony of innocence," but rather came to cleanse corruption, and this is the characteristic function of mythical cataclysms. Yeats's world, however, is not being destroyed out of wrath but of necessity. There is no agency at work, no God repaying with vengeance. The ceremony of innocence is drowned by a tide of anarchy which, though evil and murderous in itself, is nevertheless historically innocent, acting as an agent of inevitable historical necessity. ${ }^{27}$

Yeats's system included, simply put, a series of 2000-year historical cycles that would follow one another and be the previous one's antithesis, following the structure of two intersecting gyres. The cycles can be subdivided into shorter ones, and the important aspect is the simultaneity of both cycles; the apex of the one coincides with the base of the other. The end of one historical cycle and the beginning of another is followed by a period of intense violence, as Charlemagne's conquests marked the year 1000 A.D. and as the fall of Rome marked the end of the classical sub-era.

The Christian era, whose end Yeats felt drew near, was not agreeable to the poet. It was a primary, objective era, when the individual counted as part of a whole rather than as self-sufficient entity. The previous era, whose apex was the opulence of Byzantium, valued the antithetical, the subjective, and the individual. It is thus understandable that Yeats should exult at the end of the Christian era even in the face of the coming violence, as he witnessed the Great War and the escalating tension of World War II. As Vendler noted, whereas this violence was evil in itself, it was also the portent of a newly arriving, and possibly more congenial era.

Several studies have focused on A vision and related prose, explicating these cycles and Yeats's understanding of history in view of his system. Swan and shadow: Yeats's dialogue with history, by Thomas R. Whitaker, was one of the first, and is possibly still the best, study of this relation. This study's motto is the idea of dialogue, the interplay between self and subject. Yeats saw personal history and world history as reflecting one another, the history of the mind closely linked to the history of its surroundings. Whitaker focuses on the balance between freedom and fate and on the possibility of change in the cycles.

In her Yeats's Vision and later plays, Helen Vendler examines A vision as an account of aesthetic experience. Although reading it as an important volume of Yeats's oeuvre, and asking for the gravity it deserves (thus opposing the then common dismissal of the book as

\footnotetext{
${ }^{27}$ VENDLER. Yeats's Vision and later plays, p. 100.
} 
mystic mumbo-jumbo), she misses some of the important moral and philosophical issues $A$ Vision presents. The book, however, is invaluable in its clear exposition of obscure passages, using both 1925 and 1937 versions as bases.

The countess Cathleen was first printed in The countess Kathleen and various legends and lyrics, published in 1892. It was Yeats's second volume, following The wanderings of Oisin (1889), which contained a long dramatic poem and some lyrics, but no plays. The play was only to be performed in 1899, seven years after the first publication. This delay can partly be explained by The countess Cathleen's long story of revisions, which, according to Peter Ure, extended "over nearly thirty years, is lengthier than that of The shadowy waters or any other play by Yeats”. ${ }^{28}$ This long process of revision is both linked to Yeats's development as a playwright, as he included many changes after assessing what worked and not, and his biography, especially in the figure of the poet Aleel's rejection. Despite having access to the almost 800-page long The countess Cathleen manuscript materials, published in the Cornell Yeats series, and the plays variorum, I will focus on the "final" version Yeats published and included in Poems (1919) and Plays and controversies (1923).

The play is based on the story of a saintly Irish countess who, in a time of famine and despair, sells her soul to the devil in order to save the peasants around her by using the money she gets to buy food and stop them from selling their souls out of hunger. To this moral tale,

Yeats had begun by introducing an emphasis alien to his source and by refusing suggestions that might have appealed to a dramatist less concerned with the personal and the subtle. It was this re-making of the "conflict between the forces of good and evil" into a hinted choice between dreams and responsibility that was to grow progressively into a much more elaborate structure. $^{29}$

Yet, the choice between dreams and responsibility that is increasingly prominent in the play is yet another "conflict between the forces of good and evil," since doing her duty, abiding to what she sees is her responsibility, is what leads the countess to salvation in the end of the play, regardless of the great sin of selling her own soul. Rather than placing the conflict in metaphysical and overreaching terms, as it is found in the folklore source, with the devil conspiring against a whole nation, Yeats relocates the source and locus of conflict inside the countess's own consciousness. Her failure to abide to the imperative of her responsibility toward her people would probably mean her damnation, even if she had never sold her soul.

\footnotetext{
${ }^{28}$ URE. Yeats the playwright: a commentary in character and design in the major plays, p. 13.

${ }^{29}$ URE. Yeats the playwright: a commentary in character and design in the major plays, p. 20-21.
} 
Yeats’s “mystery religion” (to borrow the title of Graham Hough’s seminal book) not only included unorthodox views on damnation but also a belief in the conflation of Christianity and paganism in Irish folklore. The poet Aleel, whose prominence grew in the consecutive revisions, is the memory and heart of paganism in the play, but it is in the other peasants, less archetypical and more supposedly "truly Irish," that this syncretism most offended readers and theatergoers.

In his search for condensation and suggestion rather than exposition (made clear in the comparison between the early five-act long The countess Cathleen and the late one-act Purgatory), Yeats frequently resorted to characters who were types rather than fully developed figures. We thus have the Rua men, who follow a carpe diem philosophy and hope for the best (reassuring themselves that there is no proof of the existence of the soul), being blasphemous, base, and corrupt; Mary Rua, the pious poor, who dies with her lips tinged with green from eating dandelions rather than selling her soul; Oona, whose Christianity conforms to the practical side of life; the Countess Cathleen, whose personality is quickly established in a parallel with the Virgin Mary; and aforementioned Aleel, the romantically lost pagan poet.

Aleel is lost in many ways: his soul cannot be bought because it is lost to another, namely his love, the Countess Cathleen. For the devil merchants who buy souls in the play have a very clear set of rules in their valuing system: souls are valuable relative to their purity. Being comparable to the Virgin Mary, the countess has the most valuable soul in the play: it is a gemstone, for she is pure, innocent, and good.

From the countess's innocence also springs what is revealed as her salvation: acting from instinct, she is able to come to solutions a more learned Christian might be caught on. Giving away her best, she is able to save others, and sacrificing herself for those who may even be undeserving (most of the peasants are shown to be lecherous, murderous, and thieving), she is also comparable to Jesus Christ.

Yeats justifies her martyrdom in the face of what can be seen as the rod of Irish history: the Famine. Cataclysms have a very important characteristic for Yeats: they represent a "moment of truth," when the conflicts and distinctions between the different persons in that era are heightened. In the context of the Famine in The countess Cathleen, this "moment of truth" makes a lesser side to Irish society bloom: that of materialism. Yeats was a great critic of materialism, and it is no surprise that the most unqualifiedly evil peasants in the play (the Rua men) suffer from greed.

Avarice is also one of the sins that the Boy in Purgatory exhibits and can be said to have triggered his murder at the hands of the Old Man, his father. When the Boy tries to reach 
for the Old Man's bag of money, the Old Man awakens from his reverie and attacks the boy. Even if the murder was planned, as to relieve the soul of his mother, the Old Man is brought to action in response to the Boy's attempt at his purse.

In the absence of God, it is up to the Old Man, he thinks, to attempt at judgment and take over matters of salvation and damnation in Purgatory. The Old Man is the mouthpiece of the play, as well as a sort of anti-hero. After many of the mythological plays, and early ones such as The countess Cathleen, Yeats would turn away from his idea of the hero and focus on the type of anti-hero the Old Man represents. The Old Man is confused, deranged even, and the tension between his intentions for committing both parricide and filicide are justified within his twisted logic; the audience can never see him as an unqualified hero. As Yeats's last comment on the state of affairs in the Ireland of his time, Purgatory is much more direct, stripped of allegories, and bleak than any other play he ever did. The Old Man is closer to the audience in this play, which is one of Yeats's most naturalist pieces, but at the same time, it is clear that the Old Man's experience is to be taken very symbolically.

Even if in a context of purgatory that is, in the end and if stripped of some of the heterodoxies, close to Catholic ideas, Yeats criticizes the moral and social evils in his society. There are three possible views of evil in the play. The first would be a decontextualized view, which focuses on the crimes of homicide against a descendant and an ascendant. The second is the Old Man's view of evil and what he seeks to fight against. His is a clearly misguided but nonetheless heroic attempt to eradicate or appease the sins he is able to detect in the world around him. This view is different from Yeats's own, and should, Peter Ure has counseled, be distinguished from that. Closer to Yeats's would be the third view, that of the initiate, for whom knowledge of a greater truth (such as exposed in A vision) would help make sense of the real conflicts and the options available.

In Purgatory, tradition, violence, eugenics, agency, and the interplay of the living and the world of the dead are central topics. Knowledge of $A$ vision, however welcome, is nevertheless dispensable since the world of the play is slightly different from that exposed in Yeats's philosophy, which never accounts for the possibility of interference of human agencies; the play is successful in setting up its own scenario and the assumptions in the Old Man’s world.

In this article, I have proposed to analyze the representation of evil in two of Yeats's plays: The countess Cathleen and Purgatory. The idea of evil is central to Yeats and is part of one of his most disputed terms: the Vision of Evil. Evil, in this sense, is seen as the complementary opposite of Good, one that must be faced in order to achieve a complete 
understanding necessary for transcendence. This evil is, then, the other side of the coin of good, and thus welcomed. There are, however, other understandings of evil in Yeats's works: that which hinders the achievement of Unity of Being, for instance. In this sense, evil can be see as an obstacle to be conquered and therefore a chance for a soul to evolve. We find this kind of evil in The countess Cathleen: the Famine is an evil that brings out the best in her and leads her to her final sacrifice, one that will ultimately assure her place in heaven. As a drama focused on the heroine, this solution works for the play, but is ultimately questionable. Another type of evil is the crimes we see in Purgatory. Despite being justified in terms of the Old Man’s attempt to "end all consequence” of his mother's original sin, they are nonetheless evil and bring out no good: the Old Man cannot stop her mother's remorse. Similarly, there is condemnation of the mother's sin, and the effect is overwhelming: it leads to the end of a house, to the end of a line, to the end of a time, to the end of a civilization. As the Old Man puts it, it is a capital offence.

\section{RESUMO}

Este artigo analisa a representação do mal em duas peças de W. B. Yeats: The countess Cathleen (1892) e Purgatory (1939). Embora muito diferentes, as peças demonstram uma preocupação com a natureza do mal, a salvação ou danação da alma e o poder do indivíduo contra as forças do destino.

\section{PALAVRAS-CHAVE}

W. B. Yeats (1865-1939), The countess Cathleen [A condessa Cathleen] (1892), Purgatory [Purgatório] (1939), teatro irlandês, o mal

\section{REFERENCES}

BLAKE, William. The marriage of heaven and hell. 1793. The William Blake archive. Disponível em: <http://www.blakearchive.org>. Acesso em: 26 nov. 2008.

ELLMANN, Richard. Yeats: the man and the masks. New York: Macmillan, 1948.

FOSTER, R. F. W.B. Yeats: a life: the apprentice mage. Oxford/New York: Oxford UP, 1997.

FOSTER, R. F. Yeats and Irish politics. In: Our Time. Radio 4. BBC, London, 17 Apr. 2008.

HARPER, George Mills; KELLY, John S. Preliminary examination of the script of E[lizabeth] R[adcliffe]. In: Yeats and the occult. Ed. George Mills Harper. Toronto: Macmillan, 1975. 
HARPER, Margaret Mills. Yeats and the occult. In: HOWES, Marjorie; KELLY, John (Org.). The Cambridge companion to W. B. Yeats. Cambridge: Cambridge UP, 2006.

HOUGH, Graham. The mystery religion of W. B. Yeats. Brighton: Harvester, 1984.

JEHA, Julio. Monstros como metáforas do mal. In: na literatura. Belo Horizonte: Ed. UFMG, 2007. p. 9-31. (Org.). Monstros e monstruosidades

KEANE, Patrick J. Yeats's interactions with traditions. Columbia: U of Missouri P, 1987.

LARRIMORE, Mark (Ed.). The problem of evil: a reader. Malden: Blackwell, 2001.

NATHAN, Leonard E. The tragic drama of W. B. Yeats: figures in a dance. New York: Columbia UP, 1965.

URE, Peter. Yeats the playwright: a commentary in character and design in the major plays. New York: Barnes and Noble, 1963.

VENDLER, Helen H. Yeats's Vision and later plays. Cambridge: Harvard UP, 1963.

WHITAKER, Thomas R. Swan and shadow: Yeats's dialogue with history. Washington: Catholic U of America P, 1989.

YEATS, William Butler. Explorations. London: Macmillan, 1962.

YEATS, William Butler. The collected works of W. B. Yeats: later essays. New York: Scribner, 1994.

YEATS, William Butler. Autobiographies, reveries over childhood and youth. New York: Scribner, 1999.

YEATS, William Butler The collected works of W. B. Yeats: a vision: the original 1925 version. New York: Scribner, 2008. 